\title{
AKTIVITAS ANTIBAKTERI FRAKSI ETANOL DAUN KEMANGI (Ocimum americanum) TERHADAP Enterococcus faecalis ATCC 29212
}

\author{
Ame Suciati Setiawan*, Diani Prisinda**, Fajar Fatriadi**
}

* Departemen Farmakologi Kedokteran Gigi dan Farmakologi Bahan Alam, Fakultas Kedokteran Gigi Universitas Padjadjaran

${ }^{* *}$ Departemen Konservasi Gigi, Fakultas Kedokteran Gigi Universitas Padjadjaran

Correspondence : Ame Suciati Setiawan, Departemen Farmakologi Kedokteran Gigi dan Farmakologi Bahan Alam, Fakultas Kedokteran Gigi Universitas Padjadjaran

Email : ame.suciati@fkg.unpad.ac.id

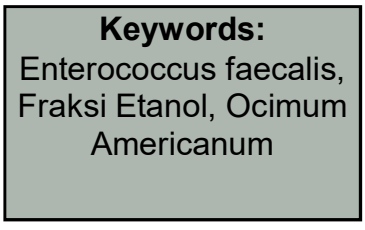

\section{ABSTRACT}

Background: Ocimum americanum (O. americanum) is a natural plant with antibacterial effects inhibits the growth of gram-positive and gram-negative anaerobic bacteria in the oral cavity. Enterococcus faecalis ( $E$. faecalis) is a gram-positive anaerobic bacteria in the root canal which is resistance to intracanal medicament. The purpose of this study is to analyze the antibacterial effect of ethanol fractionation of $O$. americanum towards E. faecalis ATCC 29212. Ocimum americanum is a natural plant that has antibacterial properties against grampositive and gram-negative anaerobic bacteria in the oral cavity. Enterococcus faecalis is an anaerobic gram-negative bacteria was found in root canals and resistant to various root canal medicament. The purpose of this study was to analyze the antibacterial effect of the ethanol fraction of Ocimum americanum against Enterococcus faecalis.

Methods: The research method was experimental used disc diffusion technique. The fraction is made from solid extract into a polar solution with ethanol solvent with concentration $20 \%, 40 \%, 60 \%$ and $80 \%$. The test was performed by measuring the inhibition zones around the disc after 24 hours.

Results: Chemical properties of O.americanum are alkaloid, flavonoid, saponin, tanin, steroid, dan terpenoid. Inhibition zone of $O$. americanum fraction with concentration $20 \%, 40 \%, 60 \%$ and $80 \%$ is $8.8 \mathrm{~cm}, 9.8 \mathrm{~cm}, 11.1 \mathrm{~cm}$ and $16.7 \mathrm{~cm}$. The measurement of $O$. americanum inhibition zone showed better results compared than positive control (Minosep).

Conclusion: Ethanol fraction of O.americanum has antibacterial effect towards E. faecalis.

\section{PENDAHULUAN}

Daun kemangi (Ocimum americanum/
O.americanum) adalah tanaman herbal yang
banyak digunakan di Asia dan Afrika.

O.americanum merupakan tanaman yang memiliki aroma yang khas dengan ketinggian $0,7 \mathrm{~m}$, tangkai yang lurus, daun oval berwarna sangat hijau, dengan bunga berwarna merah muda-putih. $O$. americanum memiliki efek antibakteri terhadap beberapa bakteri rongga mulut dan penyebab penyakit periodontal. ${ }^{1}$ Minyak esensial $O$. americanum memiliki efek antibakteri terhadap
$P$. gingivalis dan $P$. intermedia dengan konsentrasi hambat minimum $0.35 \mathrm{mg} / \mathrm{ml}$ sedangkan terhadap $F$. nucleatum 0.70 $\mathrm{mg} / \mathrm{ml}$. Konsentrasi bunuh minimum terhadap $P$. gingivalis dan $P$. intermedia adalah 0.70 $\mathrm{mg} / \mathrm{ml}$ sedangkan terhadap $F$. nucleatum adalah $1.4 \mathrm{mg} / \mathrm{ml}^{1}{ }^{1}$ Penelitian lain yang dilakukan terhadap Streptococcus mutans menunjukkan zona hambat sebesar $28 \mathrm{~mm}$ dengan konsentrasi hambat minimum $0,04 \% \mathrm{v} / \mathrm{v}$. Zona hambat terhadap 
Candida albicans dari rongga mulut menunjukkan penghambatan sebesar $>30 \mathrm{~mm}$ dengan konsentrasi hambat minimum 0,04\% v/v. Hal ini menunjukkan bahwa $O$. americanum menunjukkan efek yang baik terhadap mikroorganisme di dalam rongga mulut. ${ }^{2}$ Hasil penelitian yang dilakukan menunjukkan bahwa O. americanum memiliki efek anti bakteri terhadap bakteri anaerob gram positif dan negatif di dalam rongga mulut. ${ }^{2}$

Enterococcus faecalis (E. faecalis) adalah bakteri anaerob gram positif di dalam saluran akar yang mengalami infeksi pada jaringan periapikal, dan tetap bertahan didalamnya meskipun telah dilakukan perawatan .3,4,5 Walaupun E. faecalis ada dalam jumlah sedikit sebagai flora awal pada saluran akar gigi yag belum dilakukan perawatan, namun pada $90 \%$ gigi yang telah dirawat endodontik ditemukan E. faecalis. ${ }^{5}$

Kegagalan perawatan endodontik dapat disebabkan karena adanya bakteri $E$. faecalis yang masuk ke bagian terdalam tubuli dentin dengan cepat dan bertahan lebih lama dibandingkan dengan mikroorganisme patogen lainnya di dalam saluran akar, hal ini menimbulkan bakteri ini sangat resisten terhadap obat-obatan saluran akar. ${ }^{6,7,8}$

Ocimum sanctum dan Ocimum basilicum merupakan jenis kemangi lainnya yang memiliki efek antibakteri. Beberapa penelitian yang telah dilakukan menunjukkan efek antibakteri dari minyak esensial daun kemangi jenis Ocimum sanctum terhadap bakteri $E$. faecalis dengan konsentrasi 20.000 ppm memiliki zona hambat sebesar 11,70 $\mathrm{mm}$, konsentrasi 10.000 ppm sebesar 9,25 mm dan konsentrasi $5.000 \mathrm{ppm}$ sebesar $8,90 \mathrm{~mm}^{9}$ Penelitian lain yang dilakukan dengan menggunakan minyak esensial Ocimum basilicum konsentrasi 40.000 ppm menunjukkan tidak ada perbedaan efek yang signifikan dibandingkan dengan parachlorophenol campher menthol (ChKm). ${ }^{10}$ Hasil dari penelitian tersebut menunjukkan bahwa kedua jenis kemangi memiliki efek antibakteri terhadap E. faecalis, tetapi belum ada penelitian yang menunjukkan adanya efek antibakteri dari $\quad$ O. americanum terhadap $E$. faecalis sehingga peneliti ingin mengetahui efektivitas antibakteri dari 0 . americanum terhadap bakteri $E$. faecalis.

\section{METODE PENELITIAN}

Metode yang dilakukan adalah eksperimental dengan menguji fraksi etanol (larutan polar) dari $O$. americanum terhadap bakteri $E$. faecalis. Tanaman yang digunakan diperoleh dari Cisarua Kabupaten Bandung Barat dan dideterminasi di Sekolah IImu Teknik Hayati (SITH) Institut Teknologi Bandung. Penelitian dilakukan di Laboratorium mikrobiologi Sekolah Farmasi ITB. Daun kemangi (O. americanum) yang dikeringkan dibuat menjadi eksrak padat kemudian dilakukan fraksinasi dengan menggunakan pelarut etanol $10 \%$ untuk menghasilkan larutan polar. Hasil fraksinasi diuji fitokimia untuk melihat kandungan yang terdapat dalam ekstrak O. americanum.

Bakteri yang digunakan adalah bakteri $E$. faecalis ATCC 29212. Uji antibakteri dilakukan menggunakan metode disc diffusion method dengan mengencerkan larutan menggunakan aquades steril sampai mencapai konsentrasi $20 \%$, $40 \%, 60 \%$ dan $80 \%$ yang diteteskan pada cakram dan diukur besar zona bening yang dihasilkan di area cakram tersebut. Hasil pengukuran dibandingkan dengan Khlorheksidin (Minosep) sebagai kontrol positif.

Penelitian ini telah lulus etik melalui Komite Etik Penelitian Universitas Padjadjaran Bandung dengan nomor sertifikat Etik 1279/UN6.KEP/EC/2018 


\section{HASIL PENELITAN}

Daun kemangi diuji determinasi di Sekolah IImu Teknik Hayati Institut Teknologi Bandung, dengan spesifikasi sebagai berikut:

Divisi : Magnoliophyta

Kelas : Magnoliopsida (Dicots)

Anak kelas: Asteridae

Bangsa : Lamiales

Familia : Lamiaceae (Labiatac)

Spesies: Ocimum americanum $L$

Nama umum: Hoary basil, American basil (Inggris),

Kemangi, Selasih putih (Indonesia), Surawung

(Sunda)
Hasil inokulasi bakteri dengan perhitungan menggunakan Angka Lempeng Total ditemukan Jumlah Populasi bakteri E. faecalis $=3,3 \times 10^{7}$ dan $2,6 \times 10^{7}$. Hasil penelitian menunjukkan bahwa ekstrak etanol $O$. americanum memiliki efektivitas antibakteri terhadap bakteri $E$. faecalis. Hal ini ditunjukkan dengan adanya zona bening disekitar cakram. Larutan O. americanum memiliki zona hambat yang lebih baik dibandingkan dengan Minosep.

Tabel 1. Hasil Uji Fitokimia Ekstrak Daun Kemangi

\begin{tabular}{llcl}
\hline \multicolumn{1}{c}{ Uji sampel } & \multicolumn{1}{c}{ Pereaksi } & Hasil $+/-$ & \multicolumn{1}{c}{ Keterangan } \\
\hline \multirow{2}{*}{ Alkaloid } & $\begin{array}{l}\text { Dragendorf } \\
\text { Mayer }+\mathrm{HCl}\end{array}$ & + & $\begin{array}{l}\text { Merah } \\
\text { Endapan putih }\end{array}$ \\
\hline Flavonoid & Amil alkohol $+\mathrm{Mg}+\mathrm{HCl}$ & + & kuning \\
\hline Saponin & Air $+\mathrm{HCl}$ & + & Berbusa stabil \\
\hline \multirow{2}{*}{ Kuinon } & $\mathrm{NaOH}$ & - & $\begin{array}{l}\text { tidak ada } \\
\text { perubahan }\end{array}$ \\
\hline \multirow{2}{*}{ Tanin } & $\mathrm{FeCl}_{3} 1 \%$ & + & $\begin{array}{l}\text { Hitam } \\
\text { Endapan putih }\end{array}$ \\
\hline Steroid/ Triterpenoid & $\mathrm{H}_{2} \mathrm{SO}_{4}+$ As. asetat & + & Merah hijau biru \\
\hline
\end{tabular}

Tabel 2. Hasil pengukuran zona hambat efektivitas antibakteri ekstrak polar $\mathrm{O}$. americanum terhadap kotrol Minosep pada bakteri E. faecalis

\begin{tabular}{cccc}
\hline No. & Konsentrasi & $\begin{array}{c}\text { Ekstrak Polar O. } \\
\text { Americanum } \\
\text { (cm) }\end{array}$ & $\begin{array}{c}\text { Minosep } \\
\text { (cm) }\end{array}$ \\
\hline 1 & $80 \%$ & 16,7 & \\
\hline 2 & $60 \%$ & 11,1 & \\
\hline 3 & $40 \%$ & 9,8 & \\
\hline 4 & $20 \%$ & 8,8 & 12,1 \\
\hline 7 & $0,2 \%$ & & 10,4 \\
\hline 8 & $0,1 \%$ & & 9,4 \\
\hline 9 & $0,05 \%$ & & 7 \\
\hline 10 & $0,025 \%$ & & \\
\hline
\end{tabular}



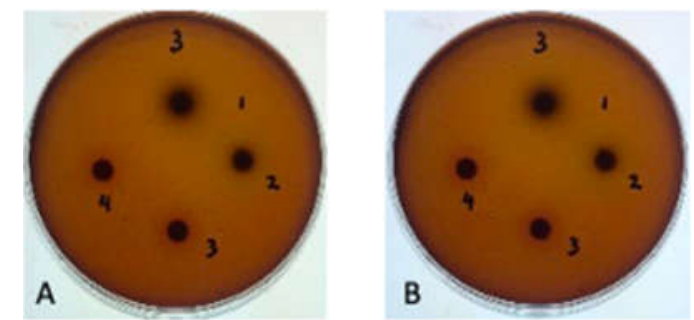

Gambar 1. Zona hambat larutan polar $O$. americanum yang dilakukan secara duplo dengan hasil pengukuran pada lempeng $(A)$ dan $(B)$ kemudian diambil nilai rata-rata dari kedua lempeng. Zona hambat dilakukan dengan menggunakan 4 konsentrasi (1) $80 \%$, (2) $60 \%$, (3) $40 \%$ dan (4) $20 \%$
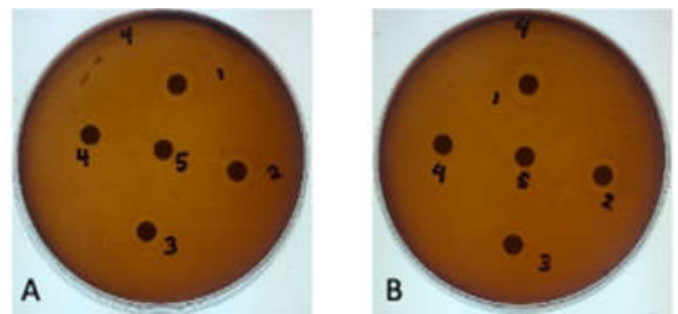

Gambar 2. Zona hambat kontrol positif (Minosep) yang dilakukan secara duplo dengan hasil pengukuran pada lempeng $(A)$ dan $(B)$ kemudian diambil nilai rata-rata dari kedua lempeng. Zona hambat dilakukan dengan menggunakan 4 konsentrasi (1) $0,2 \%$, (2) $0,1 \%$, (3) $0,05 \%$ dan (4) $0,025 \%$

\section{DISKUSI}

Enterococcus faecalis ATCC 29212 pada penelitian ini diuji coba terhadap ekstrak $O$. americanum untuk uji aktivitas antibakteri. Penelitian uji aktivitas antibakteri dilakukan pada empat konsentrasi fraksi Ocimum americanum yaitu $80 \%$, $60 \%, 40 \%$ dan $20 \%$ sedangkan untuk kontrol positif menggunakan Minosep dengan konsentrasi yaitu $0,2 \%, \quad 0,1 \%, \quad 0,05 \%$ dan $0,025 \%$. Pengujian dilakukan dengan dua kali pengulangan (duplo) dengan menggunakan metode cakram. Hasil penelitian pada tabel 2 menunjukkan semakin tinggi konsentrasi fraksi etanol O. americanum semakin besar hasil zona hambatnya. Fraksi etanol $O$. americanum pada konsentrasi $80 \%$ menunjukkan angka zona hambat $16,7 \mathrm{~mm}$. Kekuatan daya antibakteri zona hambat melalui pengukuran diameter zona hambat $5 \mathrm{~mm}$ atau kurang dikategorikan lemah, diameter zona hambat 5-10 $\mathrm{mm}$ sedang, diameter $10-20 \mathrm{~mm}$ dikategorikan kuat. Indikator kategori tersebut menunjukkan fraksi etanol O. americanum termasuk kedalam kategori antibakteri kuat.

Aktivitas antibakteri dari penelitian ini menunjukkan besarnya diameter hambat sebesar $8,8 \mathrm{~mm}$, hal ini menunjukkan bahwa $\mathrm{O}$. americanum termasuk ke dalam antibakteri sedang. ${ }^{2}$ Penelitian lain yang dilakukan Prisinda, dkk (2018) dengan pengujian antibakteri ekstrak metanol Ocimum sanctum terhadap $E$. faecalis menunjukkan diameter zona hambat minimum sebesar $8,8 \mathrm{~mm}$ tetapi pada penelitian ini metanol sebagai pelarut juga menunjukkan adanya daya hambat terhadap E. faecalis sehingga daya antibakteri yang dihasilkan oleh $\mathrm{O}$. sanctum dapat dibantu oleh adanya daya antibakteri metanol sebagai pelarut. ${ }^{9}$ Dapat disimpulkan bahwa daya antibakteri fraksi etanol O. americanum memiliki daya antibakteri yang lebih baik dibandingkan dengan $\mathrm{O}$. sanctum. Berbeda dengan penelitian minyak esensial Ocimum basilicum (O. basilicum) terhadap 
bakteri E. faecalis, menunjukkan diameter hambat minimal sebesar $9,5 \mathrm{~mm}$, lebih besar dibandingan diameter hambat minimum $\mathrm{O}$. americanum. ${ }^{10} \mathrm{Hal}$ ini dapat menunjukkan bahwa minyak esensial $O$. basilikum memiliki daya hambat lebih baik dibandingkan fraksi etanol $\mathrm{O}$. americanum.

Efek antibakteri $O$. americanum yang terjadi disebabkan adanya kandungan zat-zat aktif yang dapat menghambat pertumbuhan bakteri. Hasil uji fitokimia pada tabel 1 menunjukkan kandungan senyawa dari ekstrak etanol $O$. americanum yaitu Alkaloid, Flavonoid, Terpenoid, Saponin, dan Tanin. Flavonoid dan tanin termasuk dalam golongan senyawa fenol. Senyawa-senyawa tersebut merupakan senyawa yang aktif yang mempunyai efek antibakteri.

Mekanisme kerja flavonoid dapat meningkatkan permeabilitas membran dan hilangnya potensial membran sel bakteri. ${ }^{12}$ Senyawa fenol yang terikat dengan bakteri akan mengganggu permeabilitas membran yang mengakibatkan kation dan makromolekul dari sel hilang sehingga menyebabkan terganggunya pertumbuhan sel dan menjadi mati. ${ }^{13}$ Selain itu senyawa fenol telah banyak diteliti karena mempunyai multiple mekanisme terhadap aktivitas anti bakteri yaitu dapat berinteraksi dengan protein dan dinding bakteri, menyebabkan kerusakan membran sitoplasma, menurunkan fluiditas membran, menghambat sintesis asam nucleic, sintesis dinding atau metabolisme energi sel. ${ }^{14}$

Kontrol positif yang digunakan pada pengujian ini adalah klorheksidin glukonat (Minosep $\left.{ }^{\circledR}\right)$ dengan zona hambat $12,1 \mathrm{~mm}$ pada konsentrasi $0,2 \%$. Pengujian ini membuktikan bahwa klorheksidin mempunyai efek daya hambat kuat terhadap bakteri Enterococcus faecalis tetapi masih lebih baik efek antibakteri fraksi etanol $O$. americanum. Klorheksidin merupakan agen kation yang dapat menghambat aktivitas bakteri. ${ }^{15}$ Mekanisme antibakterinya berhubungan dengan struktur molekul kation bibisguanid. Molekul kation diserap ke membran sel dan menyebabkan kebocoran dari komponen intraselularnya. ${ }^{15}$

Klorheksidin pada konsentrasi yang rendah $(0,02 \%)$ dapat bertindak sebagai bakteriostatik sedangkan pada konsentrasi yang lebih tinggi bersifat bakterisid karena menyebabkan koagulasi dan presipitasi sitoplasma. ${ }^{6,15,16}$

\section{KESIMPULAN}

Ekstrak fraksi etanol Ocimum americanum dengan konsentrasi 80\% memberikan efek antibakteri terhadap pertumbuhan Enterococcus faecalis, ditunjukkan dengan menghasilkan diameter zona hambat $(16,7 \mathrm{~mm})$ lebih baik dibandingkan dengan Minosep 0,2 \% (12,1 mm).

\section{UCAPAN TERIMA KASIH}

Kami ingin mengucapkan banyak terima kasih kepada Universitas Padjadjaran yang telah membiayai penelitian kami dan seluruh kerabat yang terlibat dalam penelitian ini. Terima kasih atas segala bantuan dan dukungan yang diberikan

\section{DAFTAR PUSTAKA}

1. Sroisiri.T., Boonyanit.T. Phytopharmacy Journal Ocimum americanum Ocimum americanum $L$. Essential Oil Exhibits Antimicrobial Activity Against Oral Bacteria Related To Periodontal Disease. Phytopharm.2012

2. Sroisiri.T., Boonyanit.T. In Vitro Antimicrobial Activity Of Ocimum americanum L. Essential Oil Against Oral Microorganisms. South Asian J Trop Med Public Health, 2009;40:1025-1033.

3. Rocas, I.N \& Siqueira, J.F. Characterization Of Microbiota Of Root Canal Treated Teeth With Post Treatment Disease. Journal Of Clinical 
Microbiology, 2012;50(5): 1721-1724

4. Torabinejad M, Walton RE. Endodontics: Principles and Practice, 5th edition. Elsevier. 2014

5. Hargreaves KM, Berman LH. Cohen's: Pathways of The Pulp Eleventh Edition. Elsevier. 2016

6. Dammanschke. T., Jung. N., Harks. I., Schafer.E. The Effect Of Different Root Canal Medicament Of Enterococcus Faecalis Ex Vivo. European Journal Of Dentistry, 2013;7(4): 442448

7. Abbaszadegan. A., Sahebi. S., Gholami. A., Delroba. A., Kiani. A., Iraji. A. Time Dependent Antibacetrial Efects Of Aloe Vera And Zataria Multiflora Plant Essential Oils Compared To Calcium Hydroxide In Teeth Infected With Enterococcus Faecalis. Journal Of Investigative And Clinical Dentistry, 2016;7(1): 93-101

8. M.A. Mozayeni, A. Haeri, O. Dianat, A.R. Jafari. Antimicrobial Effect of Four Intracanal Medicaments On Enterococcus Faecalis; An In Vitro Study. Iranian Endodontic Journal, 2014;9(3):195-198

9. Prisinda.D., Suciati.A., Fatriadi.F. Antibacterial Potential Of Ocimum Sanctum Oils In Relation To Enterococcus Faecalis Atcc 29212. Dental Journal, 2018;51(3): 104-107

10. A.S. Setiawan., Fatriadi. F., Prisinda.D. Differences Of Basilicum Leaf (Ocimum Basilicum) Essential Oil's Inhibition Zones And Parachlorophenol (Chkm) Against Enterococcus Faecalis. International Journal Of Medical Science And Clinical Invention, 2018; 5(12): 4237-4239

11. D. Kandaswamy., Venkateshbabu N. Root canal irrigants. Journal of Conservative Dentistry 2010. 13 (4); 256-264
12. Siti S., Diki P.W., Sohadi W. Uji Anti Bakteri Obat Kumur Ekstrak Etanol Herba Kemangi (Ocimum americanum L) Terhadap Streptococcus mutans. Indonesian Journal of Pharmaceutical Science and Technology. 2012.1 (2):20-8.

13. Diah Ayu L,. Apriliana E. Efek Potensial Daun Kemangi (Ocimum basilicum L) Sebagai Pemanfaatan Hand Sanitizer. Majority. 2016. 5(5):124-128.

14. Livia Sobodnikova., Silvia Fialova et all. Antibiofilm Activity of Plant Polyphenols. Molecules. 2016. 21(1717):1-15.

15. Garg N, Garg A. Textbook of Endodontics 2nd edition. 3rd ed. India: Jaypee Brothers Medical Publishers; 201. 555

16. Horner C, Mawer D, Wilcox M. Reduced susceptibility to chlorhexidine in staphylococci: Is it increasing and does it matter? J Antimicrob Chemother. 2012;67(11):2547-59. 